\title{
Analysis Management Policy of Laboratory School in Indonesia University of Education
}

\author{
Prayoga Bestari
}

\author{
Universitas Pendidikan Indonesia, Bandung, Indonesia \\ Corresponding author.Email: yogabestari@upi.edu
}

\begin{abstract}
This research analyzes the management policy of the laboratory school of the University of Education in Indonesia, which aims to provide students with educational services, as well as a practical place for future professional teachers and a practical development place for various educational innovations. Set up. This school is a model school for the creative and innovative learning practices of potential professional teachers in cooperative schools developed in cooperation with LPTK and related district or city education offices. Planning, implementation and supervision is a form of management analysis of UPI Labschool School. The method used in this study is a qualitative case study method. The data collection techniques used in this study are: interviews, observations and literature research. The results show that the experimental school plays the role of education service provider for students in accordance with applicable regulations. It is a place for the development of various teachers and educational practices in teacher vocational education, as well as a place for the development of various educational innovations. During its development, the laboratory school developed from the direction of campus development, which was included in the strategic plan of LPTK (in this case, the Indonesian University of Education). The strategic planning related to the development of experimental schools is based on the development direction contained in the principal's regulations and various laws and regulations related to the professional development of teacher education.
\end{abstract}

Keywords: Laboratory School, Management, Policy.

\section{INTRODUCTION}

In recent years there has been a growing international trend towards decentralization, devolution and greater autonomy for schools in the general education system, with the aim of improving the quality of education [1]. The arguments put forward for increased autonomy for schools are echoes and modifications of a similar claim made to all organizations except the smallest organization in society [2]. "The decision about how to run the institution comes down to the people who know best what needs to be done". Current arguments about changes in school governance and management all point in this direction even though they go by a variety of names. Such policy reforms are known as school-based management reforms in Canada and the United States [3]

In Indonesia, in an effort to improve the quality of national learning, the government and the Ministry of National Education continue to make efforts to implement updates to the national learning system. One of the efforts that have been tried regarding the teacher aspect is the issuance of Law No. 14 of 2005 concerning Teachers and Lecturers and Government Regulation No. 19 of 2005 concerning National Learning Standards. Both regulations are government policies which include government efforts to organize and correct the quality of teachers in Indonesia. updates Learning systemdepend on how the teacher thinks and plays a role. Or in other words, updating the learning system depends on the competence of the teacher.

Reforming the national learning system and implementing learning policies requires in-depth research, linking policy reviewers and researchers with Indonesian learning practitioners. For this reason, efforts should be made to increase the competitiveness of the country's energy competitiveness by always adhering to the wisdom of local culture. Therefore, policy research and learning management are interesting research topics that must be strengthened to allocate donations for changes to the national learning system. It is believed that policy making that is not based on research results will have a major negative impact at this time, and must be a valuable experience for policy makers. This influence must be taken into account in order to properly formulate policies for the welfare of the people. [4].

The existence of a laboratory school for the Higher Education Institute (LPTK) is a must. Its position is analogous to the existence of a hospital for the medical faculty (teaching hospital) which aims to educate prospective doctors to have professional abilities. The 
position of laboratory schools for LPTKs is a vehicle for education and training for prospective teachers (teaching school). Therefore, the LPTK, which has a mission to educate prospective teachers, requires an infrastructure in the form of facilities to support the achievement of competency of professional teacher candidates.

One of the roles of laboratory schools in the LPTK is clear like other schools in general, namely to input students in the form of education and output in the form of graduates or students who have ended up learning with various predicates and the quality of graduates attached to them. Inputs in the learning system are students who want to get learning, the output is graduates or students who have ended taking learning with all the various predicates and quality of graduates attached to them. This also relates to the involvement of schools with students. School involvement is often studied as a possible antecedent of academic achievement. These constructs have been conceptualized broadly in three domains: behavioral (i.e., participation in extracurricular activities), emotional (i.e., positive and negative feelings and reactions towards school, teachers, peers), or cognitive (i.e., willingness to invest in learning skills. It is difficult and understanding of complex ideas [1]

Law Number 23 of 2014 states that the authority of the regional government is not fully limited, namely limited to aspects of financing, human resources and infrastructure. learning, evaluation, measurement, tool, learning tool, metade, study times, books and spending allocation and use of the budget, everything becomes kewenangha everything becomes kewenangha everything and use of process quality and learning outcomes in order to improve the quality of education nationwide.

But other things on on the function of the laboratory school is also a vehicle for pendi education and training for prospective teachers (teaching school), thus in this case the laboratory school has a different function from the school in general because it has other functions than the school in general. This of course affects the management, regulations or policies issued by this laboratory school, which is different from schools in general.

Management in each Laboratory school as a pilot school is certainly different from one another. Analysis of the overview of laboratory school management policies at the Indonesia University of Education is a target to be achieved in this study.

\section{THEORETICAL REVIEW}

\subsection{Education Policy}

Regulation of laws and regulations as a method and instrument exists to control and center the lives of citizens towards the desired goals. From the point of view of schooling, learning related to provisions (regulations) is in external character (provisions relating to national policies, regions and officials who have authority) and there are internal school characteristics in the form of descriptions of larger rules and for the functional needs of the school. [3]. Public policy is the way for an institution or government to solve a problem. [4]

Educational policy is related to the basic functions of educational institutions, especially educational units at all levels and education and teaching, namely: 1 . Standards and curriculum development; 2. Vision, mission, 3. development of educational personnel; 4. Management and coaching of student participants; 5. Provision of lesson novels; 6 . Provision and maintenance of learning facilities; 7. Provision and maintenance of learning facilities; 8 . Procurement, maintenance and use of the bibliotek and school laboratories, etc. which can provide support for the quality of learning [5].

On the other hand, policies related to the management of learning institutions include the allocation and use of budget resources, construction management, equipment and equipment management, and facility management. Internally, in addition to the goals that have been formally set, the school is also equipped with a set of rules, if students and school staff show good performance, are of high quality and show the expected attitude, and have empathy among personnel. The mutual relations and interactions between the two countries need to be strengthened. Positive reinforcement to keep his good mentality in good shape and be recognized. Signs of positive reinforcement are discipline, cleanness and honesty, no cheating and discrimination when dealing with offenders, and the attitude that is immediately shown is feedback [5].

Internal and external regulations in education are interrelated, external rules regulated by both central and regional governments regarding aspects of financing, human energy sources and infrastructure facilities must also be complemented by internal school policies which include curriculum, learning, assessment and measurement, learning facilities and equipment, learning procedures and time, novels and budget allocations and use of the budget all fall under the authority of the school.

Thus regulation and policy making will not only depend on central and local government policies but also the school regulation model will also be seen from the policies or regulations issued by schools internally. In addition, trust in the principal is important in the processes and outputs produced by schools [6]. Studies investigating the effect of trust in schools have shown that trust is positively correlated with the process and product of school: confidence contribute to improving achievement, a positive school climate, and effective communication between teachers, and it also empowers the work of teachers and reduce conflicts [7]

Trust between the principal and several school authorities is important to encourage the education process and generate synergies in school management. The changes involved in implementing policies and new reforms require mutual trust between principals and teachers and other stakeholders to drive the education process [8]. In other words, trust can help power holders to generate synergies in school management and ensure the development of the teaching-learning process and the sustainability of change in schools [9]. 
Taking the concept from organizational institutional theory, it describes the actors who shape and promote school-based management in the national arena, their interests, and the networks that connect them. Three categories of actors were identified: policy actors, teacher union actors, and academic actors. [10]. Educational policies are formulated to deal with perceived problems, respond to perceived needs and are based on prevailing understanding. [11]

School policies include macro policies as well as other policies that appear in the Induction Guide for School Management Teams. Consultation goes hand in hand with democratic principles such as openness and transparency. At the school level all stakeholders involved in the policy formulation process must adhere to these principles [12]. In addition, it is also necessary to sometimes use word of mouth to convey policies.

The way problems are solved in a policy context is a complex process. That being said, policies will be interpreted differently and translated differently and applied against and against current practices, sometimes simultaneously. Policies can become watery and sometimes die down. Education policy enters a different environment: schools have different histories, different buildings and infrastructure, staffing profiles and teaching and learning challenges. [13]. In policy practice, what needs to be analyzed is how policy implementation plays an important role. [14]

\subsection{Urgency of Laboratory Schools}

The existence of laboratory schools for Higher Education Institutions (LPTK) is a must. Its position is analogous to the existence of a hospital for the medical faculty (teaching hospital) which aims to educate prospective doctors to have professional abilities. The position of laboratory school for LPTK is a vehicle for education and training for prospective teachers (teaching school) [15]. Therefore, the LPTK, which has a mission to educate prospective teachers, requires an infrastructure in the form of facilities to support the achievement of competency of professional teacher candidates.

One of the roles of the laboratory school in the LPTK has become clear like other schools in general, namely to provide input to students in the form of education and output in the form of graduates or students with various predicates and high quality graduates who have completed their education are fascinated by him. Inputs in the learning system are students who want to get learning, the output is graduates or students who have ended taking learning with all the various predicates and quality of graduates who are fixated on themselves. This also relates to the involvement of schools with students. School involvement is often studied as a possible antecedent of academic achievement. These constructs have been conceptualized broadly in three domains: behavioral (i.e., participation in extracurricular activities), emotional (i.e., positive and negative feelings and reactions towards school, teachers, peers), or cognitive (i.e., willingness to invest in learning skills. difficult and understanding of complex ideas [1] aim of laboratory schools is not only to focus on students but also on prospective educators who make laboratory schools also a vehicle for education and training for prospective teachers (teaching school). management, regulation and policy making should be different from schools in general. Based on this, this study seeks to describe effective management policies applied to laboratory schools.Its implementation needs to be accompanied by strategies to build the capacity of schools, school principals and the community, which are inspired by a clear focus on improving quality and attention to equity [16]

\section{METHOD}

The approach used in this research is a qualitative approach [17]. how to research the problem. Research the problem is something procedures for the collection of information temper Integrative serta comperhensive. Integrative means using a variety of approach methods and having acharacter, namely the comprehensiveinformation collected includes the totality. With an in-depth checking method of a condition or event that is spoken of as a problem by using systematic ways of carrying out observations, gathering information, analyzing data, and reporting the results.

Based on the description above, problem research is a study strategy, an empirical study that investigates an indication in a real life setting. This strategy can incorporate qualitative facts that rely on multiple sources as well as the preceding growth of theoretical propositions. As is the case with other research objectives in general, basically the author uses the research method of researching this problem in order to master the object under study. After that the researchers sorted using a qualitative approach because it matched the nature of the problem and the objective to be obtained was to try to get a real reflection of the Laboratory School Regulatory Model at the Institute of Education and Education Personnel (LPTK).

This research wanted to describe two main cases using the following methods: 1). Analyze the policies of laboratory school management at the Indonesian Learning University (UPI), and 2). Share reflections of suggestions in the management of Laboratory Schools at the Indonesian Learning University. This research position is located at the Indonesian Learning University Laboratory School. The subjects in this research were the Principal of the School, BPS, teachers and administrative staff at the Indonesian Learning University Labschool School.

The method of collecting information used in this research is: "interviews, observation and documentation study." The field notes are through observation, interview and study, observation and documentation study.) "The field notes are through observation, interview and documentation study" [18]. These three techniques are used to obtain mutually supportive data or to meet information on the management of Laboratory Schools at the Indonesian Learning University. 


\section{RESULT AND DISCUSSION}

Based on the results of interviews with school principals, the objectives of management policies in UPI Laboratory Schools expect input and output to be in accordance with the vision and the mission that the school aspires to be based on the values of regional local wisdom as an excavator of philosophical values on a macro and micro scale. The content of the existing curriculum is the development of the 2013 Curriculum which is adjusted to the direction of the school's vision and mission, as well as superior programs that are additional supplements for achieving optimal learning.

Based on the results of interviews with the Head of BPS and the Development Team, Management is the process of empowering all resources, both human elements and material elements, efficiently and effectively for achieving goals through a well-planned, well-executed and properly supervised and evaluated process. Management Standards are criteria for overriding the planning, implementation and supervision of learning activities at the learning unit, district / city, provincial, or national level in order to achieve efficiency and effectiveness in the implementation of learning.

Based on the results of the study of laboratory school management documentation as an academic support element under the Laboratory School Management Body, in this case it is directly the responsibility of the Chancellor through the Vice Rector for Planning, Organization, and Information System. Division who has the authority to open, close, and combine operational laboratory schools. In its implementation, it is assisted by the Laboratory School Organizing Body which has the task of carrying out the implementation, implementation, supervision, coordination and development of laboratory schools, as well as the Director of Regional Campus with functions of carrying out span of authorithy and span of supervision for laboratory schools in their working areas.

Based on the results of interviews, observations, documentation studies, FGDs currently being conducted, the Labschools in the LPTKs do not yet have a national legal umbrella. In the Regulation of the Minister of Research, Technology and Higher Education of the Republic of Indonesia Number 55 of 2017 concerning Teacher Education Standards Article 1 paragraph 3 and 15 explains that each LPTK provides Laboratory Schools in learning development but until now Labschool in LPTK has different status and treatment. The status of the Indonesian University of Education Laboratory School is a private good, but the LPTK, in this case the Indonesia University of Education, has a public status. How is the management system and work relationship arrangement because until now there is no clarity. On the other hand, this Labschool is a major requirement for LPTKs for method processing, media transfer, model testing and learning evaluation, and so on. So this is the same position as the position of the laboratory of chemistry, physics, engineering, medicine, and others. Therefore it is very important to make a Permendikbud regarding the status and management of Laboratory Schools.
School development methods and strategies are using SWOT analysis where the strengths, weaknesses, opportunities and obstacles become the basic foundation for consideration in developing an effective and efficient curriculum. The implementation of curriculum evaluation is carried out regularly by looking at the output or success of the learning process of students, where every year there is a need for innovation and creation to more optimally compile an integrated curriculum.

Table 1. SWOT Analysis of Laboratory School Management, Indonesia University of Education

\begin{tabular}{|c|}
\hline Strength \\
\hline $\begin{array}{l}\text { - As a teaching school in educational innovation, and } \\
\text { collaborative research with lecturers and students in } \\
\text { developing learning models for } \\
\text { - Laboratory Schools LPTK from kindergarten, } \\
\text { elementary, junior high to high school } 90 \% \text { already } \\
\text { have operational permits and are accredited A and has } \\
\text { national and international achievements. Public } \\
\text { - perception as a quality school }\end{array}$ \\
\hline Weakness The \\
\hline $\begin{array}{l}\text { - status of Laboratory Schools that are under the } \\
\text { auspices of the LPTK, including until now has not had } \\
\text { legal standing a clearfrom the government. } \\
\text { - The current position of the laboratory school has a } \\
\text { superior or parent of } 3 \text { parties: 1) Education office; } 2 \text {. } \\
\text { University / LPTK; } 3 \text {. School Administering Bodies / } \\
\text { foundations or other agencies that organize them. }\end{array}$ \\
\hline Opportunities \\
\hline $\begin{array}{l}\text { - Kemendikbud issued Government Regulations such } \\
\text { as Government Regulation Number } 93 \text { of } 2015 \\
\text { concerning Educational Hospitals for State } \\
\text { Universities with Medical Faculties. } \\
\text { - Article } 27 \text { Paragraph (1) of Government Regulation } \\
\text { Number } 93 \text { of } 2015 \text { above, in order to coordinate the } \\
\text { entire clinical learning process at Teaching Hospitals, } \\
\text { an education coordination committee was formed. }\end{array}$ \\
\hline Threats \\
\hline $\begin{array}{l}\text { - If the legal standing of the Laboratory School is not } \\
\text { clear, it will endanger the future of the Laboratory } \\
\text { School and the LPTK. } \\
\text { - The unclear relationship between Laboratory School } \\
\text { administrators and the LPTK in this case will have the } \\
\text { potential for conflict. } \\
\text { - Setback for LPTKs including UPI PTN-BH which } \\
\text { owns a Laboratory School if it does not have a legal } \\
\text { standing. }\end{array}$ \\
\hline
\end{tabular}

(Source: Processed by Researcher)

This is in accordance with the laws and regulations as a method and the right instrument that exists to control and center the lives of citizens towards the desires that are expected. From the school's point of view, regulations (regulations) related to learning are external (regulations related to countries, regions, and authorized officials), and some are internal to formulate larger rules and school operational needs. [3]. Public policy is a way for an institution or government to solve a problem [4] 
Breakthrough school management with the complexity and multiplicity of educational objectives so that schools can use resources effectively in curriculum development to carry out educational activities according to their own characteristics and needs [20]. Schools are required to independently explore, allocate, ensure priority scale, control, and be responsible for empowering resources, both to residents and the government. [21].

Table 2.Management Laboratory Schools of Indonesia University of Education

\begin{tabular}{|c|c|c|c|}
\hline \multirow{2}{*}{$\begin{array}{l}\text { Name } \\
\text { of } \\
\text { School } \\
\text { s }\end{array}$} & \multicolumn{3}{|c|}{ Policy-makers } \\
\hline & Planning & $\begin{array}{c}\text { Impleme } \\
\text { ntation }\end{array}$ & $\begin{array}{c}\text { Of } \\
\text { Supervision }\end{array}$ \\
\hline $\begin{array}{l}\text { UPI } \\
\text { Labora } \\
\text { tory } \\
\text { School }\end{array}$ & $\begin{array}{l}\text { Principals, } \\
\text { deputy } \\
\text { principals, } \\
\text { teachers, } \\
\text { School } \\
\text { Administering } \\
\text { Bodies }\end{array}$ & $\begin{array}{l}\text { Deputy } \\
\text { Principal } \\
\text { s assisted } \\
\text { and } \\
\text { teachers }\end{array}$ & $\begin{array}{l}\text { Headmaster } \\
\text { and School } \\
\text { Administrati } \\
\text { on Agency } \\
\text { (BPS) UPI }\end{array}$ \\
\hline
\end{tabular}

(Source: Processed by Researcher)

Meanwhile, the principles of the UPI Laboratory School development policy can be seen in the table below:

Table 3.Principles of Management Principles of Laboratory Schools, Indonesia University of Education

\begin{tabular}{|c|c|c|c|c|c|}
\hline \multirow[b]{2}{*}{$\begin{array}{l}\text { Scho } \\
\text { ol } \\
\text { Name }\end{array}$} & \multicolumn{2}{|c|}{ Aspects } & \multirow[b]{2}{*}{$\begin{array}{l}\text { Auto } \\
\text { nomy }\end{array}$} & \multirow[b]{2}{*}{$\begin{array}{l}\text { Achie } \\
\text { veme } \\
\text { nt of } \\
\text { Targe } \\
\text { ts }\end{array}$} & \multirow[b]{2}{*}{$\begin{array}{l}\text { Evalu } \\
\text { ation }\end{array}$} \\
\hline & freedom & $\begin{array}{l}\text { Indepe } \\
\text { ndence }\end{array}$ & & & \\
\hline $\begin{array}{l}\text { UPI } \\
\text { Laborat } \\
\text { ry } \\
\text { Schools }\end{array}$ & $\begin{array}{l}\text { direction } \\
\text { of goals } \\
\text { and } \\
\text { achievem } \\
\text { ents of } \\
\text { students } \\
\text { by the } \\
\text { School } \\
\text { through } \\
\text { the } \\
\text { School } \\
\text { Principal } \\
\text { in } \\
\text { coordinat } \\
\text { ion with } \\
\text { the BPS }\end{array}$ & $\begin{array}{l}\text { School } \\
\text { does } \\
\text { not } \\
\text { depend } \\
\text { on the } \\
\text { LPTK } \\
\text { in } \\
\text { curricul } \\
\text { ar } \\
\text { manage } \\
\text { ment in } \\
2013 \\
\text { Curricu } \\
\text { lum } \\
\text { Separat } \\
\text { e }\end{array}$ & $\begin{array}{l}\text { mana } \\
\text { geme } \\
\text { nt } \\
\text { relate } \\
\text { d to } \\
\text { the } \\
\text { progr } \\
\text { am } \\
\text { schoo } \\
1\end{array}$ & $\begin{array}{l}\text { Visio } \\
\mathrm{n} \text { and } \\
\text { missi } \\
\text { on } \\
\text { UPI } \\
\text { Labor } \\
\text { atory } \\
\text { Scho } \\
\text { ol is } \\
\text { superi } \\
\text { or and } \\
\text { forem } \\
\text { ost in } \\
\text { know } \\
\text { ledge } \\
\text { and } \\
\text { perso } \\
\text { nality }\end{array}$ & $\begin{array}{l}\text { Asses } \\
\text { sment } \\
\text { throu } \\
\text { gh } \\
\text { mone } \\
\mathrm{v} \text { at } \\
\text { schoo } \\
1 \\
\text { intern } \\
\text { als, } \\
\text { and } \\
\text { exter } \\
\text { nally } \\
\text { with } \\
\text { BPS. }\end{array}$ \\
\hline
\end{tabular}

(Source: Processed by Researcher)

Further recommendations in the management of UPI Laboratory Schools can be seen in the image below:

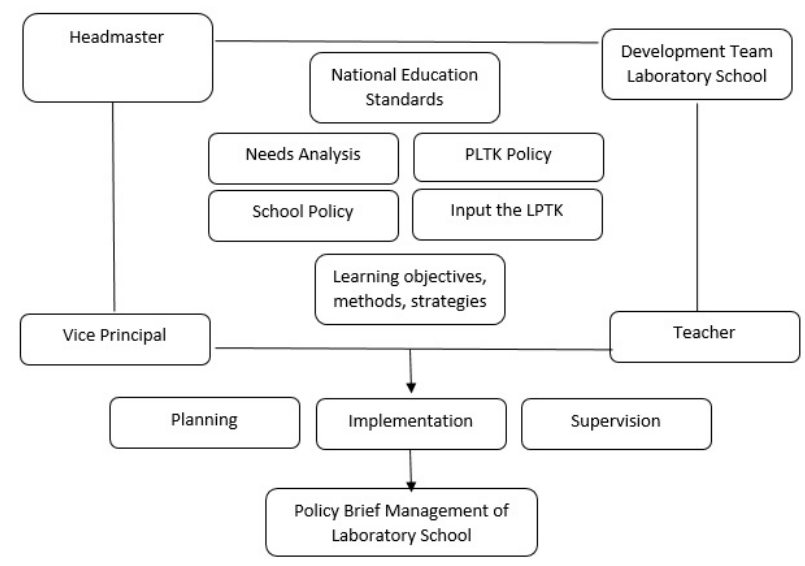

Figure. 1 The Management of UPI Laboratory Schools

(Source: Processed by Researcher)

Based on the picture above, it can be seen that management must involve stakeholders including the development team, school principals, deputy principal, teacher. Management must stick to the goals and follow the national education standards, taking into account the needs, input, input from the LPTK, school policies. This is followed by the objectives, strategies, and learning methods that are suitable for application in laboratory schools. Planning, implementation, and supervision are carried out by each unit tasked with the principles of integrity and collaboration so that the policy brief is used and is in accordance with the objectives planned at the beginning and the management flow is in accordance with the main duties and functions of each stakeholder.

Policies and virtues of learning related to the basic functions of learning institutions, especially learning units at all levels and types of learning related to learning and teaching, are: 1. Standards and curriculum development; 2. Vision, mission, goal setting, and learning objectives; 3 Recruitment and development of educational talent 4. Management and coaching of students 5. Providing learning novels 6. Provision and maintenance of learning facilities 7 . Provision and maintenance of learning facilities 8. School libraries and laboratories Purchasing, maintaining and using can provide support for the quality of learning [5 ].

On the other hand, policies related to the management of learning institutions include budget resource allocation and use, building management, equipment and equipment management, and facility management. In the school environment, in addition to the goals that have been set, the school is also equipped with a set of rules, if students, lecturers, and staff behave well, have quality and show the expected attitude, and communicate and empathize with staff. This is to obtain the necessary conditions so that his good attitude will continue to be in good condition and be recognized. The sign of positive reinforcement is justice and fair discipline, no cheating or discrimination against disciplinary offenders, they have feedback on their later attitudes. [5]. 


\section{CONCLUSION}

This study analyzes the policy of school laboratory management at the Indonesia University of Education as a school designed to provide educational services for students as well as a place to practice professional teacher candidates and a place for the development of real educational innovations. Settings. This school acts as a creative and innovative demonstration learning practice for prospective professional teachers in partner schools developed in collaboration with the LPTK and the related District or City Education Office. Planning, implementation and supervision is a form of management analysis at the UPI Labschool School. The different position of Laboratory Schools from other schools makes the need for a policy brief in carrying out the management of Laboratory Schools based on the principles of freedom, independence, autonomy, achievement targets, and evaluation. Regulations for organizing Laboratory Schools are urgently needed to provide space for development and advancement of education, especially Laboratory Schools at the Indonesia University of Education.

\section{REFERENCES}

[1] X. A. Portilla, P. J. Ballard, N. E. Adler, W. T. Boyce, and J. Obradović, "An integrative view of school functioning: Transactions between selfregulation, school engagement, and teacher-child relationship quality," Child Dev., vol. 85, no. 5, pp. 1915-1931, 2014.

[2] M. Fitrah, "Peran Kepala Sekolah Dalam Meningkatkan Mutu Pendidikan," J. Penjaminan Mutu, vol. 3, no. 1, p. 31, 2017.

[3] H. Liewarnata, B. Akbar, M. Jeddawi, and S. Lukman, "The Implementation of the Government Goods and Services Procurement Policy at the General Hospital of Sanggau Regency West Kalimantan Province," J. Public Adm. Gov., 2019.

[4] W. N. Dunn, "Pengantar Analisis Kebijakan Publik," Gadjah Mada University Press. 2003.

[5] A. Irawan and D. Satori, "Pengaruh Regulasi, Pembiayaan Dan Partisipasi Masyarakat Terhadap Efektivitas Manajemen Sarana Prasarana Sekolah, Dan Dampaknya Terhadap Efektivitas Pembelajaran Pada Sekolah Menengah Pertama Se Kota Sukabumi," J. Adm. Pendidik., vol. 17, no. 1, pp. 27-39, 2013.

[6] V. Handford and K. Leithwood, "Why teachers trust school leaders," Journal of Educational Administration. 2013.

[7] K. Arar, “Arab Principals' and Teachers' Perceptions of Trust and Regulation and Their Contribution to School Processes," Leadersh. Policy Sch., vol. 18, no. 4, pp. 648-663, 2019.
[8] T. Bush and D. Middlewood, Leading and managing people in education. 2005.

[9] L. Li, P. Hallinger, and A. Walker, "Exploring the mediating effects of trust on principal leadership and teacher professional learning in Hong Kong primary schools," Educ. Manag. Adm. Leadersh., 2016.

[10] R. T. Ogawa, "The Institutional Sources of Educational Reform: The Case of School-Based Management," vol. 31, no. 3, pp. 519-548.

[11] K. Bickmore, "Theory \& Research in Social Education Discipline for Democracy? School Districts 'Management of Conflict and Social Exclusion," no. October 2014, pp. 37-41, 2012.

[12] T. Moja and F. M. Hayward, "Higher education policy development in contemporary South Africa," High. Educ. Policy, 2000.

[13] M. Maguire, S. Ball, and A. Braun, "International Studies in Sociology of Education Behaviour, classroom management and student ' control '? enacting policy in the English secondary school," no. December 2014, pp. 37-41.

[14] Y. Gandara, "Implementasi Kebijakan Pemerintah Kota dalam Upaya Pemeliharaan Ruang Terbuka Hijau Kota Bandung," Universitas Pendidikan Indonesia, 2013. Unpublish

[15] P. Bestari, "QUOVADIS LABSCHOOL REGULATION POLICY IN LPTK," Sosiohumaniora, 2020.

[16] D. Grauwe, "School-based management ( SBM ): does it improve quality?," no. October, 2014.

[17] J. W. Cresswell and J. D. Creswell, "Research Design: Qualitative, Quantitative, and Mixed Methods Approaches," in Research Design: Qualitative, Quantitative, and Mixed Methods Approaches, 2018.

[18] S. Nasution, Metode Penelitian Naturalistik Kualitatif. Bandung: Tarsito, 1988.

[19] Y. C. Cheng, "The Theory and Characteristics of School- based Management," 2012.

[20] D. N. A. Sari, "Implementasi Manajemen Berbasis Sekolah," J. Adm. dan Manaj. Pendidik., vol. 1, pp. 213-221, 2018. 